Cronfa - Swansea University Open Access Repository

This is an author produced version of a paper published in :

The Language Learning Journal

Cronfa URL for this paper:

http://cronfa.swan.ac.uk/Record/cronfa11193

\title{
Paper:
}

Tschichold, C. (2012). French vocabulary in Encore Tricolore: do pupils have a chance?. The Language Learning Journal, 40(1), 7-19.

http://dx.doi.org/10.1080/09571736.2012.658219

This article is brought to you by Swansea University. Any person downloading material is agreeing to abide by the terms of the repository licence. Authors are personally responsible for adhering to publisher restrictions or conditions. When uploading content they are required to comply with their publisher agreement and the SHERPA RoMEO database to judge whether or not it is copyright safe to add this version of the paper to this repository. http://www.swansea.ac.uk/iss/researchsupport/cronfa-support/ 
This article was downloaded by: [Swansea University], [Cornelia Tschichold] On: 02 March 2012, At: 07: 14

Publisher: Routledge

Informa Ltd Registered in England and Wales Registered Number: 1072954 Registered

office: Mortimer House, 37-41 Mortimer Street, London W1T 3J H, UK

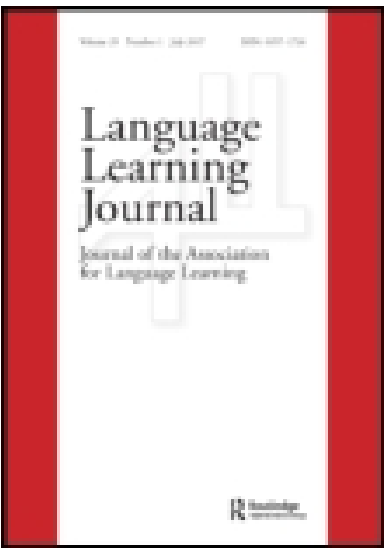

\title{
The Language Learning J ournal
}

Publication details, including instructions for authors and subscription information:

http:/ / www. tandfonline.com/loi/ rllj20

\section{French vocabulary in Encore Tricolore: do pupils have a chance?}

\author{
Cornelia Tschichold ${ }^{\text {a }}$ \\ a Department of English Language and Literature, Swansea \\ University, Swansea, UK
}

Available online: 02 Mar 2012

To cite this article: Cornelia Tschichold (2012): French vocabulary in Encore Tricolore: do pupils have a chance?, The Language Learning J ournal, 40:1, 7-19

To link to this article: http:// dx.doi.org/ 10.1080/ 09571736.2012.658219

\section{PLEASE SCROLL DOWN FOR ARTICLE}

Full terms and conditions of use: http://www.tandfonline.com/page/terms-andconditions

This article may be used for research, teaching, and private study purposes. Any substantial or systematic reproduction, redistribution, reselling, loan, sub-licensing, systematic supply, or distribution in any form to anyone is expressly forbidden.

The publisher does not give any warranty express or implied or make any representation that the contents will be complete or accurate or up to date. The accuracy of any instructions, formulae, and drug doses should be independently verified with primary sources. The publisher shall not be liable for any loss, actions, claims, proceedings, demand, or costs or damages whatsoever or howsoever caused arising directly or indirectly in connection with or arising out of the use of this material. 


\title{
French vocabulary in Encore Tricolore: do pupils have a chance?
}

\author{
Cornelia Tschichold* \\ Department of English Language and Literature, Swansea University, Swansea, UK
}

\begin{abstract}
British learners acquire very little vocabulary in their foreign languages, compared to pupils elsewhere in Europe, particularly learners of English as a foreign language. Could the materials used for teaching help explain this difference? An analysis of the vocabulary loading of a textbook for French as a foreign language commonly used in Britain, Encore Tricolore (Mascie-Taylor and Honnor, 2001, Cheltenham, UK, Nelson Thornes), was carried out with this question in mind. An analysis of the vocabulary suggests that it is not introduced and practised in a way that is conducive to building a sufficiently large vocabulary to reach level B1 of the Common European Framework of Reference for Languages (CEFR).
\end{abstract}

\section{Introduction}

The central role vocabulary plays in second-language learning is a fact language learners themselves have always recognized; as is well known they are much more likely to buy (or download) and consult a dictionary than a grammar. Their teachers, and researchers in the field, have been less constant in this respect, but vocabulary has recently returned to the centre of their attention as well. While there is no consensus on the perfect way to learn the necessary vocabulary items of a foreign language efficiently, there are a number of precepts to do with vocabulary learning that are now well established and which, consequently, learners can rightfully expect to be translated into practice in the carefully authored material used in their foreignlanguage classes. Some of these precepts are particularly relevant to learners in a situation of instructed language learning, as opposed to an immersion situation. In a foreign-language classroom context, learners cannot be expected to just 'pick up' the necessary vocabulary incidentally (Schmitt 2008); they need to put conscious effort into building their vocabulary if they want to make good progress.

Learners will need to acquire a number of separate aspects to their word knowledge, e.g. spelling and morphological forms, pronunciation, meaning and grammatical behaviour (Nation 2001), and any of these aspects can influence the amount of effort that is likely to be required by the learner in order to master it. We also know that learners will normally need multiple encounters with any given word in order to have any chance of acquiring it, and the more difficult a word is, the more encounters tend to be needed. Some of these encounters can obviously happen during reading activities, but

\footnotetext{
*Email: c.tschichold@swansea.ac.uk
} 
lower proficiency learners are unlikely to read in sufficient quantity for this to come about. For this reason, well-constructed language-learning materials should introduce and recycle new words at regular intervals to give the learners the opportunity to encounter the new words several times and in varying contexts, in order to ensure acquisition and to build learners' vocabulary systematically.

As Schmitt (2008) points out, teachers and materials writers have been slow in translating these insights into teaching practice, but if the help learners get from their teachers and their classroom materials is not good enough, learners will clearly struggle to achieve their learning goals. While we know relatively little about the oral input learners receive in the classroom (Milton 2009; but see Meara, Lightbown and Halter 1997 and Horst 2009 for examples of classroom talk), there are indications that the input learners receive from their teachers is normally heavily influenced by the materials used in class (Anderson 2007). Non-native teachers especially tend to rely heavily on their textbooks. It seems to make sense, therefore, to take a detailed look at the vocabulary in a course book when looking for factors that lead to success (or lack of it) in learning modern foreign languages. As in linguistics in general, most of the research on vocabulary acquisition has been done on English, either as a first or a second language, and it is assumed that the main findings at least can be applied to the learning of other foreign languages.

In this paper, I want to examine the vocabulary used in one British textbook for French as a foreign language, Encore Tricolore (Mascie-Taylor and Honnor 2001). French has a long tradition of being widely taught as a second language in British schools; and books used for the purpose could therefore easily be tested and improved over the years. However, as in a self-fulfilling prophecy, the idea that native speakers of English are bad at foreign languages seems to have become true for many British school leavers, who are barely able to communicate in the foreign language that they have learnt at school. A number of reasons have been suggested for this, e.g. the way competence in the foreign language is tested, or the fact that English-speaking learners are at a clear disadvantage when compared to learners of English as foreign language (EFL) due to the status of English as the uncontested world language (Dörnyei and Csizèr 2002; Graham 2004). The latter would at least help to account for the increasing gap in British and Continental school leavers' competence in foreign languages (Milton and Meara 1998; David 2008; Milton 2009). Looking for possible reasons for both this competence differential and the relatively poor foreign language skills of British school leavers, Milton (2006: 187) mentions the vocabulary that appears in British textbooks as a potential contributor to the problem and draws attention to our lack of knowledge in this area more generally: 'There is almost no information in the current literature about the French foreign language lexis that is learned in schools today.' Milton (2006) also shows that British learners have unexpectedly low levels of vocabulary after several years of learning French in school. At the time of their GCSE exams (taken at age 16), British learners were shown to have an average receptive vocabulary size of fewer than 1000 words (see also Milton and Meara 1998). David (2008) also comes to the conclusion that British learners of French have relatively small vocabularies and speculates that this might be due to the quantitatively and qualitatively deficient vocabulary exposure these learners receive.

To what extent might the vocabulary content of the textbook used contribute to the disappointing level of French vocabulary that British learners achieve at school? In order to investigate this, the vocabulary of Encore Tricolore, a commonly used set 
of textbooks for French as a foreign language in Britain, was examined. The publisher's website describes Encore Tricolore as 'much-loved', 'extensively used' and as 'the best-selling GCSE French course for middle to higher ability students'. 'The first three volumes are designed to be used for Key Stage 3 (ages 11-14), the fourth volume for Key Stage 4 (ages 14-16). Each volume has a total of 10 units, so each unit is meant to be covered over several weeks of a school year. An individual unit typically consists of eight or nine subunits, which in turn are divided into several smaller sections, all relating to the topic of the unit, such as food or travel. Most of the small sections are listening or reading passages, but there are also task instructions, grammar sections ('dossier langue') and 'lexique' sections of varying length where new vocabulary items are listed alongside their translational equivalents.

The vocabulary presented in the Encore Tricolore course was compared to the GCSE list (WJEC 2010) and to the words listed in the francais fondamental, a list of French words widely accepted as representing basic common French vocabulary (Gougenheim 1958; Gougenheim et al. 1964), even if parts of it are somewhat dated now (Christ and Christ 2006; Tidball and Treffers-Daller 2007). The vocabulary in Volume 4 of Encore Tricolore was also analysed further to gain an impression of the range and amount of repetition for individual items. The aim was to find out if the pedagogy of the lexical material might help contribute to the low level of vocabulary knowledge found in British learners. There are other factors that might contribute to the success or failure of foreign-language learning in school such as the individual learner's ability, their previous knowledge and motivation, and the quality of the teaching provided. These can be expected to vary quite widely, while the teaching material normally remains the same for a number of years. This provides a justification for examining the course book material before looking elsewhere for causes contributing to the learning outcome.

It should be kept in mind that British learners of French are not likely to have much linguistic input in French outside their school lessons and any homework they might do. This renders their task more difficult than the one facing EFL learners in many countries, where English has become ubiquitous and is often widely used as a lingua franca.

\section{How many words should learners learn?}

If the levels of vocabulary knowledge in learners are considered low, this begs the question: how much vocabulary should they know? The learners we are concerned with here (11-year-olds) cannot be expected to reach anything like a near-native vocabulary size in the timeframe given. The four volumes of Encore Tricolore are used over four school years, with two or three lessons per week. Depending on the exact length of a lesson, this normally adds up to less than 100 hours per school year. According to Atkinson and Davies (2011), this should take learners to the A2 or B1 stage of the Common European Framework of Reference for Languages (CEFR). What can be expected therefore is a level of competence in the foreign language that allows for simple communication in routine situations. But how many words are needed to make basic conversations with French speakers possible and to allow learners to build on this knowledge in case they want to go on to become more proficient? In his comprehensive overview of vocabulary learning, Nation (2001) gives the figure of 2000 words in English as the absolute minimum of words every 
learner should know, no matter what the ultimate aim of language learning is. There are indications that learners of languages other than English as a foreign language can reach this level with somewhat fewer words (Milton 2009). In order to be able to function more autonomously in the foreign language, and to continue to improve their linguistic competence through reading, for example, learners would need to know about 3000 word families, which amounts to about 5000 lemmas in English. A vocabulary of this size gives about $95 \%$ coverage of authentic written texts, just enough to allow comprehension of the text as a whole (Nation 2001). It is thought that such a basis makes incidental vocabulary learning from authentic materials possible, and can therefore be seen as a justification for CEFR's level B1 being the lowest level to provide independence. While Nation (2001) focuses on English as a foreign language, there is no reason to believe that French or other similarly developed languages would require radically smaller vocabularies to enable a learner to master basic communicative situations. French has a more complex morphology than English, so individual lemmas have more word form members, resulting in a larger number of forms, especially verb forms, that need to be learned, but the number of concepts that speakers would want to be able to name in basic conversations can be expected to be similar in closely related languages and cultures such as French and English. A target figure of somewhere between 2000 and 5000 words would seem to be a realistic aim for foreign-language learners achieving B1 level therefore. Taking into account that the users of Encore Tricolore probably have fewer classroom hours than many EFL learners (Milton and Meara 1998), it is likely that the lower figure would be more relevant.

\section{A core vocabulary for French as a foreign language}

The francais fondamental (Gougenheim 1958) represents an influential attempt at specifying the vocabulary and grammar needed for basic conversations in French. The words were largely chosen from a small oral corpus first by frequency then by range across individual conversations, before other words were added to allow important topics such as health to be covered. The resulting list contains a total of over 3000 words, with 1500 words belonging to the français fondamental $1^{\text {er }}$ degré, the bare minimum considered absolutely essential. Christ and Christ (2006) point out that the francais fondamental in general, and this core list of 1500 words in particular, has been a guiding source for French-language material writers in various countries, and even provided the basis for similar lists for German as a foreign language. The $1^{\text {er }}$ degré list stipulated the target for the first two years of teaching French as a foreign language in at least one German state and was used to provide almost the entire target vocabulary in a particularly popular textbook for French in Germany. After this initial stage with its emphasis on basic oral language, the intention was to expand the vocabulary by taking more written vocabulary into consideration. A total of 3000 words may therefore be a realistic figure for learners of French as a foreign language, divided into two halves, with the first 1500 words being the bare minimum for simple oral conversations and the second 1500 taking the learner to a level where more independent learning becomes possible. It is difficult to find clear figures about the expected total size of the target vocabulary for French as a foreign language at level B1 in British government documents or teaching material (cf. also Häcker 2008). There are, however, guidelines for GCSE French provided by examining boards, which includes a list of the 'minimum Core Vocabulary for 
Foundation Tier' (e.g. WJEC 2010: 31). This list contains about 1500 items, the same size as the français fondamental $1^{e r}$ degré.

\section{What we know about learning vocabulary in a foreign language}

Assuming the target figure for our learners of French is somewhere in the vicinity of 3000 words, including a critical core list of 1500 lexical words in addition to the main grammatical words, how can we ensure the material used in the classroom gives them the necessary input? One of the more robust findings of research on vocabulary learning is the importance of repetition. Knowing a word involves too much knowledge to be mastered in a single encounter of the target word. The number of repetitions needed per word will depend on the learner, but also on the size of the learning burden each word presents. The learning burden of words differs quite significantly depending on the language pairing and a number of other factors, e.g. nouns are easier to learn than verbs (Laufer 1997). It is also easy to see that cognates present a considerably lighter learning burden than words that are not related in form (Swan 1997). Furthermore, frequent words seem to be acquired more easily (Lotto and de Groot 1998), at least as long as they are not polysemous (Swan 1997). Depending on the learning burden, individual words may need 20 repetitions or more before they are sufficiently memorized in the long-term mental lexicon and mastered for production (Nation 2001). For English-speaking learners of French, the main learning burden at the beginners' and intermediate level is probably not the meaning - given the high number of cognates, a feature taken advantage of in Encore Tricolore - but the exact form, pronunciation and the morphological variation for many words. Because of the high proportion of English words that are cognate with French, it is assumed that it is relatively easy for English-speaking learners to develop a receptive knowledge of French quite quickly, but that it takes comparatively more effort to bring the productive knowledge up to a similar level.

Rydland and Aukrust (2005) draw attention to the kind of repetition needed for efficient vocabulary learning. While simple repetition where the same material is studied repeatedly is clearly useful, it is the more complex type of repetition that includes an element of expansion or reformulation that is most beneficial for progress with productive language use. Based on this, it might reasonably be assumed that the focus in teaching material aimed at British learners of French will clearly be on the expansion and reformulation end of repetition and recycling, rather than the simple repetition in identical contexts. In order to incorporate sufficient numbers of occurrences of any one word, with variations to the morphological form and the syntactic and semantic context, the total amount of text needed in a textbook is likely to be quite substantial.

If a sufficient number of repetitions, simple or complex, for individual words in the teaching materials is difficult to achieve for materials writers, another feature that promotes vocabulary learning is even more of a challenge for them. Teaching lists of semantically related words together, such as a series of colour terms, or a list of items of clothing, is known to make the learners' task of vocabulary acquisition more difficult (Tinkham 1997) and should therefore be avoided. Course designers understandably like to present groups of words, such as items of clothing, in lists where each item can substitute for another member of the group in a sentence pattern, but such lexical sets have a negative effect on the learning burden for these words. Learners can quite easily end up knowing only to which group a word 
belongs. The same principle applies to antonyms. Thematically related words such as dog - bark - bone, on the other hand, help acquisition.

The Encore Tricolore textbook will therefore be examined with these three principles in mind. We will be looking for sufficient numbers of lexical items overall, sufficient repetition and variation, and helpful grouping of new words.

\section{Preparation of the corpus}

The publishers of Encore Tricolore were contacted, but could not supply the text corpus or similar electronic material suitable for the purpose of this study. Therefore the lesson content of Volume 4 of Encore Tricolore was scanned and read with an optical character recognition (OCR) program. The resulting files were tagged for the unit and page number, and all images and English texts were removed. The corpus thus derived consisted of about 80,000 words, less than a typical novel. A concordancing program was then used to produce lists of word types with their frequencies. In the next step, a number of words were removed from these lists, i.e. proper names, names of countries and their inhabitants, the words for the days of the week and the months, number words, and any remaining English words (but not English words that are used as loanwords in French such as tennis or week-end) in order to make the Encore Tricolore list comparable to other word lists which also customarily do not count these groups of words (despite the fact that they do need to be learnt). This resulted in a list containing 5716 French words, which were then lemmatized semi-automatically, giving 3291 lemmas.

In the next step, grammatical and some very high-frequency words were removed, again to make the list comparable to the francais fondamental, giving a final list of 3248 lemmas. Due to the nature of concordancing, the Encore Tricolore list does not include any multi-word lexemes in their entirety, but only the components of any such items. The words removed at this stage were the prepositions de and $\grave{a}$ with all their forms, all determiners and personal pronouns, possessive adjectives and very high-frequency prepositions and conjunctions.

In addition to the lesson content of Volume 4, the glossaries of all four volumes of Encore Tricolore were also scanned and treated in the same way, in order to give an impression of the vocabulary loading across the four volumes. The glossaries were assumed to give an approximate picture of the progression over the four volumes, and the more detailed examination of Volume 4 was expected to give an impression of how new words were introduced and the amount of repetition and recycling provided after the first occurrence.

\section{Are there enough words? The glossaries}

First, the glossaries of all four volumes of Encore Tricolore were compared in order to gauge the vocabulary input over the course of the textbook series. The lists in the glossaries were compared in size after deleting the same entries as in the Volume 4 corpus, i.e. high-frequency grammatical words, multi-word units composed of elements present elsewhere, e.g. vieille ville, à la une, and names of countries and their inhabitants, the months, and the days of the week. Multiple inflected verb forms and regularly formed masculine and feminine versions (e.g. of professions, agriculteur agricultrice, or voisin - voisine) were counted as one item. Table 1 shows the number of entries thus arrived at in each of the glossaries. 
Table 1. Number of glossary entries including repetitions from earlier volumes.

\begin{tabular}{lc}
\hline Encore Tricolore & Number of entries in glossary \\
\hline Volume 1 & 946 \\
Volume 2 & 1234 \\
Volume 3 & 1692 \\
Volume 4 & 2779 \\
\hline
\end{tabular}

After an initial burst of vocabulary presentation in Volume 1 of nearly 1000 items, there is comparatively little new vocabulary introduced in Volumes 2 and 3. Volume 4 then appears to present a second burst of vocabulary input. From this, we cannot, however, infer that the number of glossary entries in each of the four volumes faithfully reflects the expected vocabulary growth over the four years. Glossaries might also have the role of listing words that only occur once and are not among the words the materials writers intended the learners to acquire in the long term. As learners become more proficient, they could be given more authentic texts that contain some less frequent or more informal vocabulary items. Glossing these will enable learners to cope with unknown words and help them understand the text at hand. Whether or not learners will remember these rarer words might not be considered very relevant by the materials writers. Despite these caveats, the glossaries could reasonably be expected to list the large majority of words appearing in each volume, if only to serve as a quick dictionary for learners and teachers. It appears that the lexical input of the textbook falls short of the 3000 words suggested as the reasonable minimum.

It would be reasonable to assume that words appearing just once in a glossary and then not listed in the glossaries of subsequent volumes are words outside the target vocabulary of approximately 3000 words. It is noticeable that quite a large number of words seem to fall out in later volumes, possibly indicating that significant numbers of words are introduced that are not part of this target vocabulary. This is not a problem as such, but the relatively high proportion in the early vocabulary does seem striking. The hapax entries that only occur in the glossary of Volume 1 (and not in any of the glossaries of Volumes 2-4) are shown in Table 2. The words have been grouped into four sections according to their reappearance in the lesson content of Volume 4 (but not the glossary of that volume), on the one hand, and according to their membership of the francais fondamental list, on the other.

For words that are not listed in the francais fondamental, the appearance in this list is perhaps not too surprising as they might well be outside the list of target words of the course books. Words that appear in the lesson content, but not in any glossary beyond that of Volume 1, probably should not cause any major worries as such, except perhaps to the proofreader of Encore Tricolore, as learners are not likely to use the glossary as their primary input for learning. This leaves the first group of hapaxes, those that are part of francais fondamental, but do not appear in the lesson content of the whole of Volume 4 of Encore Tricolore. The snapshot offered by the 12 words in this group seems surprising at first sight. With the exception perhaps of ornement and rat, all of the words are clearly part of a basic vocabulary in contemporary French, and probably present at least a modest learning burden to the English-speaking learner of French. 
Table 2. Hapax entries from the glossary of Volume 1 of Encore Tricolore.

\begin{tabular}{|c|c|c|c|}
\hline & \multicolumn{2}{|c|}{$\begin{array}{l}\text { Words that do not appear in the } \\
\text { lesson content of Volume } 4\end{array}$} & $\begin{array}{l}\text { Words that appear in the } \\
\text { lesson content of Volume } 4\end{array}$ \\
\hline $\begin{array}{l}\text { Words in the } \\
\text { francais } \\
\text { fondamental }\end{array}$ & $\begin{array}{l}\text { attentivement } \\
\text { avancer } \\
\text { cage } \\
\text { désespérer } \\
\text { grammaire } \\
\text { mécanique }\end{array}$ & $\begin{array}{l}\text { ornement } \\
\text { punir } \\
\text { rang } \\
\text { rat } \\
\text { sage } \\
\text { tais-toi, } \\
\text { taisez-vous (se taire) }\end{array}$ & $\begin{array}{l}\text { chasser } \\
\text { composé de (composer) } \\
\text { illustré (illustrer) } \\
\text { marin } \\
\text { prononcer, se prononcer } \\
\text { visite }\end{array}$ \\
\hline $\begin{array}{l}\text { Words not in the } \\
\text { francais } \\
\text { fondamental }\end{array}$ & $\begin{array}{l}\text { aigre } \\
\text { automate } \\
\text { boxe } \\
\text { caserne (de pompiers) } \\
\text { cassette } \\
\text { citrouille } \\
\text { colorier } \\
\text { dodo } \\
\text { figurine animée }\end{array}$ & $\begin{array}{l}\text { horizontalement } \\
\text { manettes } \\
\text { parasol } \\
\text { paravent } \\
\text { poulette } \\
\text { sofa } \\
\text { tombola } \\
\text { verticalement } \\
\text { vote }\end{array}$ & $\begin{array}{l}\text { anorak } \\
\text { classique } \\
\text { (jour) férié } \\
\text { passeport } \\
\text { rappel } \\
\text { sommaire } \\
\text { typique }\end{array}$ \\
\hline
\end{tabular}

Having examined the glossaries, the vocabulary content of the remainder of Volume 4 of Encore Tricolore can be examined. The total number of (lexical) lemmas in the volume is 3248. If the words are not just lemmatized (bringing together, for example, the infinitive form of the verb afficher ['stick up'] with the past participle affiché), and grouped into word families (e.g. where the corresponding noun affiche ['poster', 'notice'] is added to the verb forms), there are 2316 word families appearing at least once over the 10 lessons of Volume 4 (see Bauer and Nation 1983 for the concept of 'word family' in language learning). As a maximum figure which includes some words that occur only once in the text and may not be intended for learning, this seems somewhat low for a course designed to lead to CEFR level B1 over four years, and appears to confirm Milton's (2009) figures pointing to the higher vocabulary load of language courses for French as a foreign language in Spain and Greece. In these countries, learners at the A2 and B1 level have vocabularies at least double that of their British counterparts. It also appears low in comparison with EFL course book loading. Ramsey (1981), for example, suggests Spanish learners of English are introduced to 800-1000 words in their first year of EFL, then 1700-2000 more in year 2, and another 2500-3000 in year 3 of English lessons, so 5000-6000 lemmas over three years of EFL (a number which the author considers to be too low).

\section{Differences between le français fondamental and GCSE core vocabulary}

The overlap of these core vocabularies is very high, and most of the differences between the GCSE and français fondamental lists can be explained by somewhat different treatment of grammatical words, multi-word lexemes and cognates. It seems fair to say that this vocabulary occurs practically in its entirety in Encore Tricolore. What we cannot say is whether students get enough exposure over the four years to fully master this bare minimum.

To compare the words in Volume 4 of Encore Tricolore with those in the français fondamental list, the same words were removed from the latter list as had been 


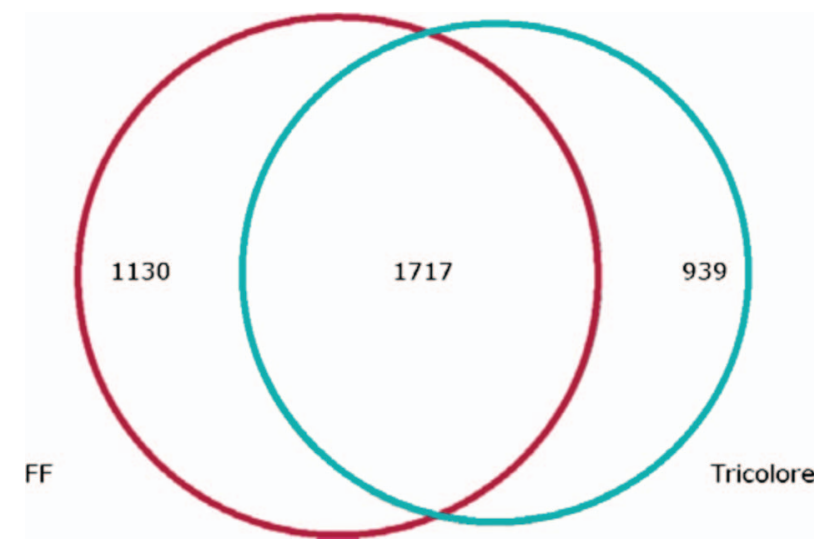

Figure 1. Proportional Venn diagram of the word families found in the francais fondamental and Encore Tricolore.

removed from the Encore Tricolore corpus, and the remaining words were grouped into word families. The notion of word family, though not without its problems in a vocabulary learning context, can be very useful here as a tool to compare the two word lists. The Encore Tricolore corpus from Volume 4 contains a total of 2656 word families, while the français fondamental list shrinks to 2847 word families. The two figures are quite close, so one could imagine that the basic vocabulary is covered well in the course book. However, the overlap between the two lists is only 1717 word families as is shown in Figure 1.

Some of the differences between the two vocabulary syllabi can of course be explained relatively easily. The French list is now somewhat dated, covering topics much less relevant to learners today, and does not contain words the compilers thought too informal. So there are a number of valid reasons for adding to the words in the francais fondamental list. If a thematic word group is rather small, materials developers might add a few items to provide more choice for exercises (cf. the list of professions and hobbies in Tricolore), or to give a better coverage of contemporary vocabulary (cf. the words marked as slang in Encore Tricolore, the ICT words, or words on French institutions such as SNCF in Tricolore). Conversely, some of the more dated or specialized words from the francais fondamental list, e.g. those from the field of agriculture, can probably be dropped without endangering the learners' ability to communicate with their peers in the second-language culture. Such measures have been taken by the authors of other textbooks for French as a foreign language (Christ and Christ 2006). To give an example, the word paysan 'peasant' and sacrifice have been dropped, and instead we find the words péage 'toll' and safari. The changes that have been introduced clearly update the vocabulary, a change which includes a number of anglicismes, loanwords from English which have become lexicalized in modern French, especially colloquial French.

A notable difference, however, is the number of verbs the lists contain. The francais fondamental list contains 997 (746 regular verbs in -er, 78 in -ir and 173 others). Encore Tricolore Volume 4 has 488, of which 374 are regular verbs in -er, 36 in -ir and 78 others. Given that verbs have a higher learning burden, this is, along with the anglicismes, a change to make the task of the learners easier. The tendency is clearly towards fewer verbs, with their many morphological forms, and more nouns, 
especially easy nouns. What is perhaps more surprising is that among the words not in the Encore Tricolore corpus, we find several dozen words that appear among the 1000 most frequent words in the French language.

We can, I think, now draw a first conclusion from this. The vocabulary loading of Encore Tricolore appears light, probably too light when compared to courses in French as a foreign language taught elsewhere, as hypothesized in Milton (2009). This is based less on raw numbers - though there is an argument for that too - than on the kinds of differences with the français fondamental list, such as fewer verbs and more easy words overall.

\section{Repetition and grouping}

Can we at least assume then that learners using this course book will know the words they are exposed to really well because they are appropriately recycled? Table 3 gives some examples of the words introduced in the 'lexique' section in the first of the 10 units of Volume 4, with the numbers of re-occurrences later on in the course book.

Of the 38 hapax lexemes introduced and not recycled later, some will have been introduced in earlier volumes and could be assumed to be at least partially known. Some have a light learning burden because they have English cognates. In these cases repetition is clearly less essential for learners. Comprehension is virtually assured, and the learning requirements for productive purposes are relatively light. If the 16 lemmas that could be considered to be cognate with English words are disregarded, this leaves 22 lemmas out of a total of 95 lemmas in the 'lexique' section of Unit 1, including deceptively simple ones such as French sensible, a 'false friend', which is translated in the unit as English sensitive. Not recycling words such as this makes it very difficult for learners to have a fair chance of acquiring this type of word in its French sense and not end up with a mistaken mental representation.

Unit 1 in Encore Tricolore Volume 4 serves in part as a unit for repetition, a fact which is very evident in the 'dossier langue' section. These boxes cover a variety of

Table 3. Words from the 'lexique' section of Unit 1 in Encore Tricolore Volume $4(n=95)$.

Number of later

units where

word re-occurs

Total words

Examples of words

0

1

2

3

4

5

6

7

$8-9$
38

20

14

10

2

6

3

2

0 bracelet, casquette, divorcé, écharpe, fleuri, généreux, gilet, indicatif, manteau, maquillage, paresseux, pyjama, retraité, robe, sensible, timide

aimable, chaussettes, chemise, composer, drôle, jupe, maillot, sympathique

célibataire, chaussures, content, haut, méchant, positif, uni

ceinture, dehors, gentil, pantalon, sérieux, timbres cousin, seul

agréable, fort, sympa

difficile, ennuyeux, vêtements

amusant, intéressant 
Table 4. Words from the 'lexique' section in Unit 2 of Encore Tricolore Volume $4(n=150)$.

\begin{tabular}{|c|c|c|}
\hline $\begin{array}{l}\text { Number of later units } \\
\text { where word re-occurs }\end{array}$ & $\begin{array}{c}\text { Total } \\
\text { words }\end{array}$ & Examples \\
\hline 0 & 46 & $\begin{array}{l}\text { baignoire, canard, cathédrale, colline, cueillir, déchets, } \\
\text { fauteuil, gaspiller, jeter, oiseau, passage, pelouse, } \\
\text { réutiliser, rideaux, soucoupe, vache }\end{array}$ \\
\hline 1 & 32 & $\begin{array}{l}\text { armoire, balcon, chaise, couteau, cuillère, descendre, } \\
\text { fermier, fleurs, plancher, réduire, robinet, trier }\end{array}$ \\
\hline 2 & 26 & $\begin{array}{l}\text { aéroport, arbre, ciseaux, frontière, lessive, patinoire, } \\
\text { paysage, port }\end{array}$ \\
\hline 3 & 21 & centre, clef, escalier, municipal, musée, protéger, villages \\
\hline 4 & 15 & auberge (de jeunesse), bâtiment, coin, montagne, plage \\
\hline 5 & 4 & bois, énergie \\
\hline 6 & 1 & piscine \\
\hline 7 & 4 & cuisine, restaurant \\
\hline 8 & 0 & \\
\hline
\end{tabular}

grammar points, including question formation, noun phrase agreement, and the present tense of French regular verbs. In Unit 2, the number of words listed in the 'lexique' boxes is considerably higher, but the number of hapax legomena is also high.

There seems to be a strong reliance on the learners themselves or on the teachers to provide the necessary number of repetitions for these words. This is especially worrying for the verbs which have a more general meaning and are often employed in more diverse contexts than the types of nouns we see here. The nouns are often given as lists of items that can slot into a given sentence pattern, the typical semantic grouping known to hinder vocabulary learning (Tinkham 1997). Examples of such semantic grouping can be seen in Unit 1.6 (items of clothing) and Unit 6 on food. Thematic grouping also occurs, with Unit 7.1 on hobbies being a good example.

\section{Concluding remarks}

For the examination of the vocabulary content of Encore Tricolore, the working hypotheses were that the textbook may contain an insufficient number of words to be useful for learners at this stage in their learning process and that the vocabulary that was introduced would be presented in a less than helpful order and context. Furthermore, the context of the book being used in British schools, with mostly English native speaker learners would lead one to expect an emphasis on the more complex type of repetition because of the relatively light learning burden of many words. In addition, the frequent use of semantic sets when introducing and teaching vocabulary seems to hinder rather than help vocabulary acquisition.

Both of these hypotheses have been confirmed to some extent. While the number of word families in Encore Tricolore Volume 4 is not that much smaller than that in the francais fondamental, the differences consistently go into the direction of making things easier for learners and avoiding items that are not completely regular. To give just one example, the francais fondamental list has 
entries for the second conjugation verb ravir 'enchant' and the corresponding adjective ravissant 'enchanting'. In Encore Tricolore, only the adjective ravi 'enchanted' or 'delighted' is used. This is derived from the past participle and is a perfectly regular adjective. It can of course be argued that the content of the francais fondamental contains some outdated words which are perhaps not the most useful words to learn for teenage learners. If the authors of Tricolore have decided to replace these words from the francais fondamental list with words that have a higher frequency in contemporary spoken language and even with some slang words, this is clearly an understandable decision. But cutting down on a substantial number of words which are common and frequent, but carry a higher learning burden is not doing learners a favour. De Groot and Keijzer (2000: 45) consider the possible motives for the inclusion of many cognates in course books: either to give learners a motivating experience at the beginning of their foreignlanguage experience, or to quickly get learners to a large enough vocabulary that allows them to read authentic texts on their own. Whether skewing the core vocabulary towards too many words with a light learning burden can still achieve the second aim seems doubtful, however. The gender system and the morphology of verbs in French offer abundant opportunities for complex repetition of the core vocabulary, and foregoing much of this deprives the learners of many chances to develop their vocabulary. The learning curve that results from showing the learner more tokens of the same word rather than a variation may well be too flat to push the learner's cognitive state forward.

\section{Note}

1. See www.nelsonthornes.com/wps/portal/secondary/modern-languages/tricolore-total-4 (accessed May 2011).

\section{References}

Anderson, B. 2007. Pedagogical rules and their relationship to frequency in the input: observational and empirical data from L2 French. Applied Linguistics 28, no. 2: 286-308.

Atkinson, T. and G. Davies. 2011. Computer-aided assessment (CAA) and language learning. Module 4.1. In Information and Communications Technology for Language Teachers ICT4LT, ed. G. Davies. Slough, UK: Thames Valley University. http://www.ict4lt.org/en/ en_mod4-1.htm (accessed May 15, 2011).

Bauer, L. and I.S.P. Nation. 1993. Word families. International Journal of Lexicography 6: 253-79.

Christ, H. and I. Christ. 2006. Le Français fondamental und sein Einfluss auf den Französischunterricht in Deutschland [Français fondamental and its influence on the teaching of French in Germany]. Französisch Heute 37, no. 4: 322-5.

David, A. 2008. Vocabulary breadth in French L2 learners. The Language Learning Journal 36, no. 2: $167-80$.

de Groot, A.M.B. and R. Keijzer. 2000. What is hard to learn is easy to forget: the roles of word concreteness, cognate status, and word frequency in foreign-language vocabulary learning and forgetting. Language Learning 50, no. 1: 1-56.

Dörnyei, Z. and K. Czisèr. 2002. Some dynamics of language attitudes and motivation: results of a longitudinal nationwide survey. Applied Linguistics 23, no. 4: 421-62.

Gougenheim, G. 1958. Dictionnaire fondamental de la langue francaise. Paris: Didier.

Gougenheim, G., R. Michéa, P. Rivenc and A. Sauvageot. 1964. L'élaboration du français fondamental $1^{\text {er }}$ degré: Etude sur l'établissement d'un vocabulaire et d'une grammaire de base. Paris: Didier.

Graham, S. 2004. Giving up on modern foreign languages? Students' perceptions of learning French. The Modern Language Journal 88, no. 2: 171-91. 
Häcker, M. 2008. Eleven pets and 20 ways to express one's opinion: the vocabulary learners of German acquire at English secondary schools. The Language Learning Journal 36: 215-26.

Horst, M. 2009. Revisiting classrooms as lexical environments. In Lexical Processing in Second Language Learners, ed. T. Fitzpatrick and A. Barfield, 53-66. Bristol, UK: Multilingual Matters.

Laufer, B. 1997. What's in a word that makes it hard or easy: some intralexical factors that affect the learning of words. In Vocabulary: Description, Acquisition and Pedagogy, ed. N. Schmitt and M. McCarthy, 140-55. Cambridge: Cambridge University Press.

Lotto, L. and A. de Groot. 1998. Effects of learning method and word type on acquiring vocabulary in an unfamiliar language. Language Learning 48: 31-69.

Mascie-Taylor, H. and S. Honnor. 2001. Encore Tricolore: Nouvelle édition. Cheltenham, UK: Nelson Thornes.

Meara, P., P. Lightbown and R. Halter. 1997. Classrooms as lexical environments. Language Teaching Research 1, no. 1: 28-47.

Milton, J. 2006. Language lite? Learning French vocabulary in school. French Language Studies 16: 187-205.

Milton, J. 2009. Measuring Second Language Vocabulary Acquisition. Bristol, UK: Multilingual Matters.

Milton, J. and P. Meara. 1998. Are the British really bad at learning foreign languages? The Language Learning Journal 18: 68-76.

Nation, I.S.P. 2001. Learning Vocabulary in Another Language. Cambridge: Cambridge University Press.

Ramsey, R. 1981. A technique for interlingual lexico-semantic comparison: the lexigram. TESOL Quarterly 15, no. 1: 15-24.

Rydland, V. and V.G. Aukrust. 2005. Lexical repetition in second language learners' peer play interaction. Language Learning 55, no. 2: 229-74.

Schmitt, N. 2008. Instructed second language vocabulary learning. Language Teaching Research 12, no. 3: 329-63.

Swan, M. 1997. The influence of the mother tongue on second language vocabulary acquisition and use. In Vocabulary: Description, Acquisition and Pedagogy, ed. N. Schmitt and M. McCarthy, 156-80. Cambridge: Cambridge University Press.

Tidball, F. and J. Treffers-Daller. 2007. Exploring measures of vocabulary richness in semispontaneous French speech: a quest for the holy grail? In Modelling and Assessing Vocabulary Knowledge, ed. H. Daller, J. Milton and J. Treffers-Daller, 144-9. Cambridge: Cambridge University Press.

Tinkham, T. 1997. The effects of semantic and thematic clustering on the learning of second language vocabulary. Second Language Research 13, no. 2: 138-63.

WJEC. 2010. GCSE French. http://www.wjec.co.uk/uploads/publications/4388.pdf (accessed April 15, 2011). 